\title{
THYROID HORMONE REGULATION OF CARDIAC GLYCOGEN METABOLISM*
}

\author{
K. Roger Hornbrook, $†$ Paul V. Quinn, John H. Siegel $\ddagger$ \\ AND THEODORE M. Brody \\ Department of Pharmacology, The University of Michigan Medical School, \\ Ann Arbor, Mich., U.S.A.
}

(Received 4 January 1965; accepted 5 February 1965)

\begin{abstract}
The administration of thyroxin to rats (500 $\mu \mathrm{g}$ daily for $2-3$ weeks, $500 \mu \mathrm{g}$ daily for 1 week, or $50 \mu \mathrm{g}$ daily for 2 weeks) or triiodothyronine (100 $\mu \mathrm{g}$ daily for 3-5 days) increased cardiac phosphorylase $a$ levels. Total cardiac phosphorylase activity was unchanged. Pretreatment with reserpine prevented and the $\beta$-adrenergic blocking agents reduced this thyroxin-induced increase in phosphorylase $a$. Thyroxin or triiodothyronine treatment potentiated the response of cardiac phosphorylase to exogeneously administered catecholamines. This enhancement of the catecholamineinduced increase in phosphorylase $a$ could be clearly demonstrated after the animals were pretreated with reserpine. Dose-response relationships for these agents are illustrated. Glycogen analyses on the same hearts indicated a parallelism between the increase in phosphorylase $a$ and the reduction in glycogen content. While hearts of thyroidectomized animals showed a decrease in phosphorylase $a$ levels and an increase in glycogen relative to controls, the response after catecholamines was unchanged. These data suggest that thyroxin may enhance these catecholamine responses by modulation of the myocardial metabolic adrenergic receptor.
\end{abstract}

THE interdependence of the action of the thyroid hormones and the catecholamines has been known for a long time and was recently emphasized by Brewster et al. ${ }^{1}$ who demonstrated the necessity of intact sympathetic pathways for certain metabolic and cardiovascular actions of thyroxin. This relationship has been extensively reviewed. ${ }^{1-3}$ While the augmentation of the effects of catecholamines by the thyroid hormone has not been universally demonstrated, ${ }^{4-7}$ a hypothesis of thyroid action has been suggested by numerous investigators, which is based upon the thesis that this hormone either alters the effective concentration of catecholamines or regulates the magnitude of the response to these amines..$^{8-13}$

Insight into a locus of action of the thyroid hormone has been provided by the observation that thyroxin elevates the level of myocardial phosphorylase $a$ and decreases myocardial glycogen..$^{14}$ This present investigation is an extension of that study and suggests that thyroid hormone and norepinephrine interact with respect to

* Supported by a contract from the Department of the Navy, Office of Naval Research, Nonr-1224 (27). A preliminary report of this study has been presented in Fed. Proc. 23, 562 (1964). Mo.

$\dagger$ Present address: Dept. of Pharmacology, Washington University School of Medicine, St. Louis,

$\ddagger$ Dept. of Surgery, The University of Michigan Medical School, Ann Arbor, Mich. 
myocardial phosphorylase activation and glycogen loss. It is proposed that the observed activation of cardiac phosphorylase by thyroid hormone is mediated by a.n increase in receptor sensitivity to catecholamines.

\section{METHODS}

White female rats (180-200 g, Holtzman strain) were used in all experiments. Hexobarbital sodium (120-150 mg/kg, j.p.) was used for anesthesia.

The excised tissues were frozen in a beaker of isopentane immersed in an alcoholdry ice mixture. Phosphorylase activity and glycogen content were determined on portions of the same tissue sample. Glycogen was isolated according to the method of Hassid and Abraham ${ }^{15}$ and glucose determined by the method of Nelson. ${ }^{16}$

Phosphorylase activity was assayed according to the method of Cori and Illingworth ${ }^{17}$ as described previously. ${ }^{14}$ Since total phosphorylase values never changed, phosphorylase $a$ values are always presented as percentage of the total.

Catecholamine infusions were performed under hexobarbital anesthesia through the exterior jugular vein of the rat with a Phipps and Bird model 71-045 $\mathrm{Cm}_{4}$ infusion pump having a delivery rate of $0.04 \mathrm{ml} / \mathrm{min}$. All dilutions of catecholamines were made in $0.9 \% \mathrm{NaCl} 0.1 \% \mathrm{NaHSO}_{3}$ and all infusions were of 5 -min duration. The control groups not receiving the catecholamines were infused with the same volume of saline--bisulfite solution. Infusion of the saline-bisulfite solution alone was without effect on the phosphorylase $a$ and glycogen levels of the heart.

Thyroidectomy was performed under ether anesthesia. During the postoperative period the animals received $1 \% \mathrm{CaCl}_{2}$ in their drinking water. Thyroidectomized animals were not used before 28 days after surgery. In the sham operated-rats, a midline incision was made in the neck under ether anesthesia. The thyroids were exposed but not removed and the incision sutured as in the thyroidectomized animals.

All experiments were randomized on a temporal basis. At least one saline control and one animal receiving norepinephrine only were studied in each group. The other animals in the group received various treatments described below. From 6 to 16 rats were assayed on the same day.

l-Thyroxin sodium (obtained from the Nutritional Biochemicals Corp.) and triiodothyronine were dissolved in alkaline isotonic saline. Solutions of the thyroid hormones were injected into rats daily by the s.c. route. Control animals received daily injections of the vehicle. Dichloroisoproterenol (DCI), administered s.c. in a dose of $10 \mathrm{mg} / \mathrm{kg} 30 \mathrm{~min}$ prior to sacrifice, was obtained from the Aldrich Chemical Co. Nethalide [2-isopropylamine-1-(2-naphthyl)ethanol hydrochloride], administered in a dose of $10 \mathrm{mg} / \mathrm{kg}$ s.c. $30 \mathrm{~min}$ prior to sacrifice, was generously supplied by Dr. J. W. Black, Imperial Chemical Industries, Ltd. Trimethidinium bismethosulfate (Ostensin, Wyeth Lab., Inc) was injected s.c. in a dose of $50 \mathrm{mg} / \mathrm{kg} 12 \mathrm{hr}$ prior to sacrifice. Reserpine $(2.5 \mathrm{mg} / \mathrm{kg}$ given i.p. $12 \mathrm{hr}$ prior to sacrifice) was obtained from the Supravite Corp. Norepinephrine was diluted daily from a commercial solution (Levophed, Winthrop-Sterling) or from an acidified stock solution of crystalline $l$ norepinephrine obtained from Winthrop Labs.

Data were analyzed for significance by Student's $t$ test and for interaction of thyroid hormones with norepinephrine (potentiation) by means of the $2 \times 2$ factorial analysis of variance for unequal sample sizes. $P$ values below 0.05 were considered to be statistically significant. 18 


\section{RESULTS}

Effect of thyroid hormone treatment on cardiac size

The hearts from rats which received $500 \mu \mathrm{g}$ per day of thyroxin for 2-3 weeks showed an average increase in wet weight of 47 per cent over control values. However, there was no difference in the protein concentration of the hearts in the two groups. Rats injected with $500 \mu \mathrm{g}$ thyroxin daily for 1 week or $50 \mu \mathrm{g}$ daily for 2 weeks had cardiac weight increases of 25 and 28 per cent, respectively, when compared to untreated controls. Triiodothyronine ( $100 \mu \mathrm{g}$ daily for $3-5$ days) produced a 30 per cent increase in heart weight. Cardiac hypertrophy with thyroid hormone has been previously observed. ${ }^{19,} 20$

While the daily doses of thyroxin and triiodothyronine used in the study appear to be excessively large in comparison with the amount of hormone normally secreted by the rat, such doses were used to produce a thyrotoxic state and a significant increase in the cardiac phosphorylase $a$ levels. With these treatments the animals also failed to gain weight at the same rate as untreated controls, although the animals so treated did not actually lose weight during the period of hormone treatment.

Thyroxin-treated animals given reserpine $12 \mathrm{hr}$ prior to sacrifice had an average body weight loss of 20 per cent during that time. Similar observations have been previously reported. ${ }^{12}$ This weight loss did not result entirely from a decreased food intake, since a similar loss was not observed in 12-hr-fasted control animals similarly treated with reserpine.

Phosphorylase response to thyroxin and autonomic blocking agents

In Table 1 are shown the effects of thyroxin treatment upon cardiac phosphorylase $a$ levels and glycogen content. Also shown are changes in these variables in hearts

TABle 1. THE INFLUENCE OF SEVERAL AUTONOMIC AGENTS ON THE CARDIAC PHOSPHORYLASE AND GLYCOGEN RESPONSE TO CHRONIC THYROXIN TREATMENT*

\begin{tabular}{|c|c|c|c|c|}
\hline Treatment & $\mathbf{N}$ & $\begin{array}{c}\text { Phosphorylase } a, \\
(\%)\end{array}$ & $\mathbf{N}$ & $\begin{array}{c}\text { Glycogen, } \\
(\mathrm{mg} / \mathrm{g})\end{array}$ \\
\hline Control & 43 & $14.2 \pm 0.8$ & 33 & $3.49 \pm 0.09$ \\
\hline Thyroxin (500 ug/day, 14-20 days) & 43 & $32 \cdot 8 \pm 2 \cdot 0$ & 25 & $2.19 \pm 0.13$ \\
\hline Nethalide $(10 \mathrm{mg} / \mathrm{kg}, 30 \mathrm{~min})$ & 8 & $11 \cdot 6 \pm 1 \cdot 3$ & 8 & $3.56 \pm 0.26$ \\
\hline Thyroxin i nethalide & 8 & $22 \cdot 3 \perp 1 \cdot 7$ & 7 & $1.82+0.22$ \\
\hline Reserpine $(2.5 \mathrm{mg} / \mathrm{kg}, 12 \mathrm{hr})$ & 23 & $12 \cdot 0 \pm 0.3$ & 19 & $5.55 \pm 0.27$ \\
\hline Thyroxin + reserpine & 20 & $14 \cdot 7 \pm 1 \cdot 2$ & 12 & $2.57 \pm 0.20$ \\
\hline Trimethidinium ( $50 \mathrm{mg} / \mathrm{kg}, 12 \mathrm{hr}$ ) & 8 & $11.4-0.8$ & 8 & $3.24 \pm 0.34$ \\
\hline Thyroxin $-t$ trimethidinium & 14 & $31.6+1.6$ & 13 & $2.12 \pm 0.21$ \\
\hline
\end{tabular}

* For both tables, values are means t- S.E.; $N$ equals number of animals per treatment. Thyroxin vs. control, $\mathbf{P}<0.01$ (phosphorylase $a$ and glycogen). Thyroxin + nethalide vs. control or thyroxin, $\mathbf{P}<0.001$ (phosphorylase $a$ ). Thyroxin + reserpine vs. thyroxin, $\mathrm{P}<0 \cdot 001$ (phosphorylase $a$ ). Reserpine vs. control, $\mathrm{P}<0.05$.

of thyroxin-treated animals produced by certain agents capable of blocking or reducing cardiac response to sympathomimetic agents. The data clearly demonstrate that thyroxin treatment alone elevated phosphorylase $a$ levels in the heart and markedly reduced cardiac glycogen. Total phosphorylase activity in the heart was unchanged by thyroxin pretreatment. Cardiac phosphorylase $a$ levels were elevated if the thyroxin 
treatment was shortened to 1 week at the same dose level $(500 \mu \mathrm{g} /$ day $)$ or the amount of thyroxin administered daily was reduced to $50 \mu \mathrm{g}$ (Fig. 1). The glycogen levels in the hearts of animals receiving the lower dose of thyroxin were not significantly different from untreated controls, while at the higher dose level $(500 \mu \mathrm{g} /$ day for 1 week) there was a significant fall in cardiac glycogen.

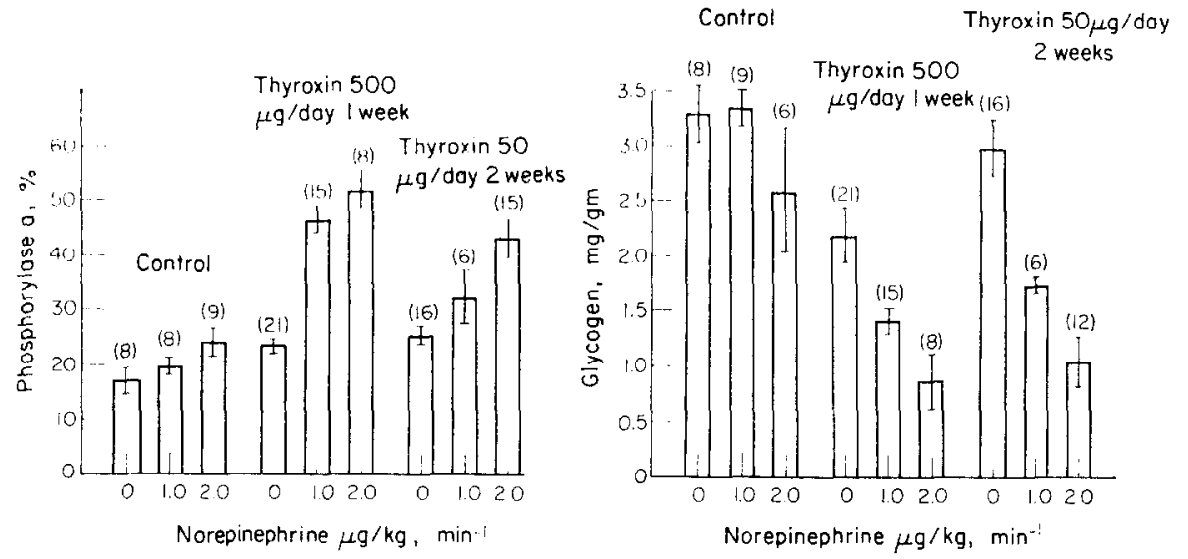

FIG. 1. The effect of norepinephrine $\left(1.0\right.$ and $\left.2.0 \mu \mathrm{g} / \mathrm{kg} \cdot \mathrm{min}^{-1}\right)$ on phosphorylase $a$ and glycogen content of rat heart in animals receiving thyroxin at two dose levels $(500 \mu \mathrm{g} /$ day for 1 week and 50 $\mu \mathrm{g} /$ day for 2 weeks). Control animals received the alkaline saline solvent daily. Those animals not infused with norepinephrine were given an equal volume of bisulfite-saline solution. The data are plotted as mean values \pm S.E. The numbers in parentheses indicate the number of animals per treatment. All phosphorylase $a$ increases after the thyroxin treatments are significantly different from untreated control $(\mathrm{P}<0.02)$. The glycogen value after thyroxin treatment $(500 \mu \mathrm{g} /$ day for 1 week) is significantly different from control $(\mathrm{P}<0.02)$. Interaction of $2 \mu \mathrm{g}$ norepinephrine/ $\mathrm{kg}$ and thyroxin $(50 \mu \mathrm{g})$ and 1.0 and $2.0 \mu \mathrm{g}$ norepinephrine and $500 \mu \mathrm{g}$ thyroxin was significant at the $\mathbf{P}<0.05$ level for phosphorylase $a$. For glycogen loss, interaction of thyroxin $(50 \mu \mathrm{g})$ and 1.0 and $2.0 \mu \mathrm{g}$ norepinephrine was significant at $\mathrm{P}<0.05$.

Treatment of the thyrotoxic animals with the $\beta$-adrenergic blocking agent, nethalide, in doses which were capable of blocking completely the action of exogenously administered catecholamine on phosphorylase $a$ levels, caused a partial reduction of the thyroxin-induced elevation of cardiac phosphorylase $a$ levels (Table 1). While phosphorylase $a$ levels in hearts of thyrotoxic animals were reduced by the $\beta$-blocking agent, myocardial glycogen levels were not higher than those receiving only thyroxin. Hearts from thyroxin-treated rats contained $2.19 \mathrm{mg}$ glycogen $/ \mathrm{g}$; and after nethalide treatment in thyrotoxic animals the glycogen was $1.82 \mathrm{mg} / \mathrm{g}$, not significantly different from thyroxin alone (Table 1). Nethalide did not influence the cardiac phosphorylase $a$ or glycogen levels in untreated control animals.

The effects of reserpine on heart phosphorylase $a$ and glycogen levels in the normal rat have been previously reported. ${ }^{14}$ From the earlier study and the data presented here it would appear that reserpine treatment does significantly reduce phosphorylase $a$ levels, although this reduction is barely significant (Table 1). In these animals this dose of reserpine produced a marked elevation in cardiac glycogen, considerably in excess of that anticipated, considering the minimal reduction in phosphorylase $a$. 
Treatment of the thyrotoxic rat with reserpine, under conditions which largely deplete the myocardium of catecholamines, completely abolished the thyroxin-induced elevation in phosphorylase $a$. However, the cardiac glycogen level of the thyrotoxic rat was unchanged by reserpine treatment even though there was ample time for glycogen synthesis.

To determine whether or not the thyroxin-induced elevation of cardiac phosphorylase $a$ originated from reflex effects, thyroxin-treated rats were given trimethidinium bismethosulfate, a long-acting ganglion blocking agent. The dose of trimethidinium administered has been shown in our laboratory to produce long-lasting blockade in the rat. Failure to reduce the phosphorylase $a$ levels with this drug (Table 1) made it appear unlikely that the thyroid-induced increased phosphorylase $a$ was either mediated reflexly or was secondary to central stimulation, since such effects should normally be abolished by ganglionic blockade.

\section{Effect of norepinephrine infusion on cardiac phosphorylase a and glycogen levels of thyroxin-treated rats}

Phosphorylase $a$ and glycogen levels after norepinephrine infusion were determined in four groups: (1) untreated controls; (2) animals treated with $500 \mu \mathrm{g}$ thyroxin for 14-20 days; (3) animals receiving $2.5 \mathrm{mg}$ reserpine $/ \mathrm{kg} 12 \mathrm{hr}$ previously; and (4) animals receiving both the thyroxin and reserpine treatments. The data from these experiments are shown in Table 2 and the log dose-response plot for these data is

TABLE 2. THE EFFECT OF NOREPINEPHRINE INFUSION ON CARDIAC PHOSPHORYLASE $A$ AND GLYCOGEN LEVELS AFTER VARIOUS TREATMENTS

\begin{tabular}{|c|c|c|c|c|c|c|}
\hline Treatment & $\mathrm{N}$ & $\begin{array}{c}\text { Phosphorylase } a \\
(\%)\end{array}$ & $\begin{array}{l}\Delta \text { From } \\
\text { control }\end{array}$ & $\mathbf{N}$ & $\underset{(\mathrm{mg} / \mathrm{g})}{\text { Glycogen }}$ & $\begin{array}{l}\Delta \text { From } \\
\text { control }\end{array}$ \\
\hline $\begin{array}{l}\text { 1. Saline control } \\
+ \text { Norepinenhrine }\end{array}$ & 43 & $14 \cdot 2+0 \cdot 8$ & & 33 & $3.49 \pm 0.09$ & \\
\hline $\begin{array}{l}0.5 \mu \mathrm{g} / \mathrm{kg} \cdot \min (5 \mathrm{~min}) \\
1.0 \mu \mathrm{g} / \mathrm{kg} \cdot \min (5 \mathrm{~min}) \\
2.0 \mu \mathrm{g} / \mathrm{kg} \cdot \min (5 \mathrm{~min})\end{array}$ & $\begin{array}{r}8 \\
10 \\
28\end{array}$ & $\begin{array}{l}11 \cdot 6 \pm 1 \cdot 2 \\
21.5 \pm 2.5 \\
32 \cdot 3 \pm 1 \cdot 6\end{array}$ & $\begin{array}{r}2 \cdot 6 \\
+\quad 7 \cdot 3 \\
+18 \cdot 1\end{array}$ & $\begin{array}{r}6 \\
8 \\
28\end{array}$ & $\begin{array}{l}3.82 \pm 0.22 \\
2.99 \pm 0.34 \\
2.31 \pm 0.13\end{array}$ & $\begin{array}{l}+0 \cdot 33 \\
-0 \cdot 50 \\
-1 \cdot 18\end{array}$ \\
\hline $\begin{array}{l}\text { 2. Thyroxin }(500 \mu \mathrm{g} / \text { day }) \\
1420 \text { days } \\
+ \text { Norepinephrine }\end{array}$ & 43 & $32 \cdot 8 \pm 2 \cdot 0$ & & 25 & $2 \cdot 19 \pm 0 \cdot 13$ & \\
\hline $\begin{array}{l}0.5 \mu \mathrm{g} / \mathrm{kg} \cdot \min (5 \mathrm{~min}) \\
1.0 \mu \mathrm{g} / \mathrm{kg} \cdot \min (5 \mathrm{~min}) \\
2.0 \mu \mathrm{g} / \mathrm{kg} \cdot \min (5 \mathrm{~min})\end{array}$ & $\begin{array}{r}9 \\
10 \\
8\end{array}$ & $\begin{array}{l}36 \cdot 4 \pm 4 \cdot 3 \\
52 \cdot 6 \pm 4 \cdot 2 \\
57 \cdot 8 \pm 1 \cdot 2\end{array}$ & $\begin{array}{l}+3 \cdot 6 \\
+19.8^{*} \\
+25 \cdot 0\end{array}$ & $\begin{array}{r}10 \\
8 \\
8\end{array}$ & $\begin{array}{l}1.72 \pm 0.26 \\
0.55 \pm 0.20 \\
0.29 \pm 0.16\end{array}$ & $\begin{array}{l}-0.47 \\
-1.64^{*} \\
-1.90^{*}\end{array}$ \\
\hline $\begin{array}{l}\text { 3. Reserpine } \\
2.5 \mathrm{mg} / \mathrm{kg}(12 \mathrm{hr}) \\
+ \text { Norepinephrine }\end{array}$ & 23 & $12 \cdot 0 \pm 0 \cdot 3$ & & 19 & $5 \cdot 55 \pm 0 \cdot 27$ & \\
\hline $\begin{array}{l}0.5 \mu \mathrm{g} / \mathrm{kg} \cdot \min (5 \mathrm{~min}) \\
1.0 \mu \mathrm{g} / \mathrm{kg} \cdot \min (5 \mathrm{~min}) \\
2.0 \mu \mathrm{g} / \mathrm{kg} \cdot \min (5 \mathrm{~min})\end{array}$ & $\begin{array}{r}7 \\
10 \\
9\end{array}$ & $\begin{array}{rl}7 \cdot 7 & 1.8 \\
19 \cdot 5 & +1.4 \\
32 \cdot 5 & 3.4\end{array}$ & $\begin{array}{r}-4 \cdot 3 \\
+\quad 7 \cdot 5 \\
+20 \cdot 5\end{array}$ & $\begin{array}{l}5 \\
7 \\
9\end{array}$ & $\begin{array}{l}6.45+0.83 \\
6.14 \pm 0.32 \\
5.55 \pm 0.28\end{array}$ & $\begin{array}{r}0.90 \\
+0.59 \\
0.0\end{array}$ \\
\hline $\begin{array}{l}\text { 4. Thyroxin }+ \text { reserpine } \\
\text { (treatment as above) } \\
+ \text { Norepinephrine }\end{array}$ & 20 & $14.7 \perp 1 \cdot 2$ & & 12 & $2.57 \perp 0.20$ & \\
\hline $\begin{array}{l}0.5 \mu \mathrm{g} / \mathrm{kg} \cdot \min (5 \mathrm{~min}) \\
1.0 \mu \mathrm{g} / \mathrm{kg} \cdot \min (5 \mathrm{~min}) \\
2.0 \mu \mathrm{g} / \mathrm{kg} \cdot \min (5 \mathrm{~min})\end{array}$ & $\begin{array}{r}10 \\
10 \\
5\end{array}$ & $\begin{array}{l}28 \cdot 2 \pm 3 \cdot 9 \\
42 \cdot 7 \pm 6 \cdot 5 \\
51 \cdot 8 \pm 5 \cdot 2\end{array}$ & $\begin{array}{l}+13.5 \dagger \\
+28.0 \dagger \\
+37.1 \dagger\end{array}$ & $\begin{array}{r}10 \\
7 \\
5\end{array}$ & $\begin{array}{l}2.26 \pm 0.35 \\
1.68 \pm 0.43 \\
0.78 \perp 0.23\end{array}$ & $\begin{array}{l}-0.31 \\
-0.89 \dagger \\
-1.79 \dagger\end{array}$ \\
\hline
\end{tabular}

* Interaction of thyroxin and norepinephrine, $\mathrm{P}<0.05$, compared to euthyroid animals.

$\dagger$ Interaction of thyroxin and norepinephrine, $P<0.05$, compared to reserpine-treated animals. 
illustrated in Fig. 2. Reference points for control values (i.e. those animals pretreated as above but infused with saline rather than norepinephrine) are indicated by the unbroken horizontal bars in Fic. 2.

In euthyroid animals, the lowest dose of norepinephrine infused $\left(0.5 \mu \mathrm{g} / \mathrm{kg} \cdot \mathrm{min}^{-1}\right)$ for 5 min did not produce a significant rise in cardiac phosphorylase $a$ or a decrease

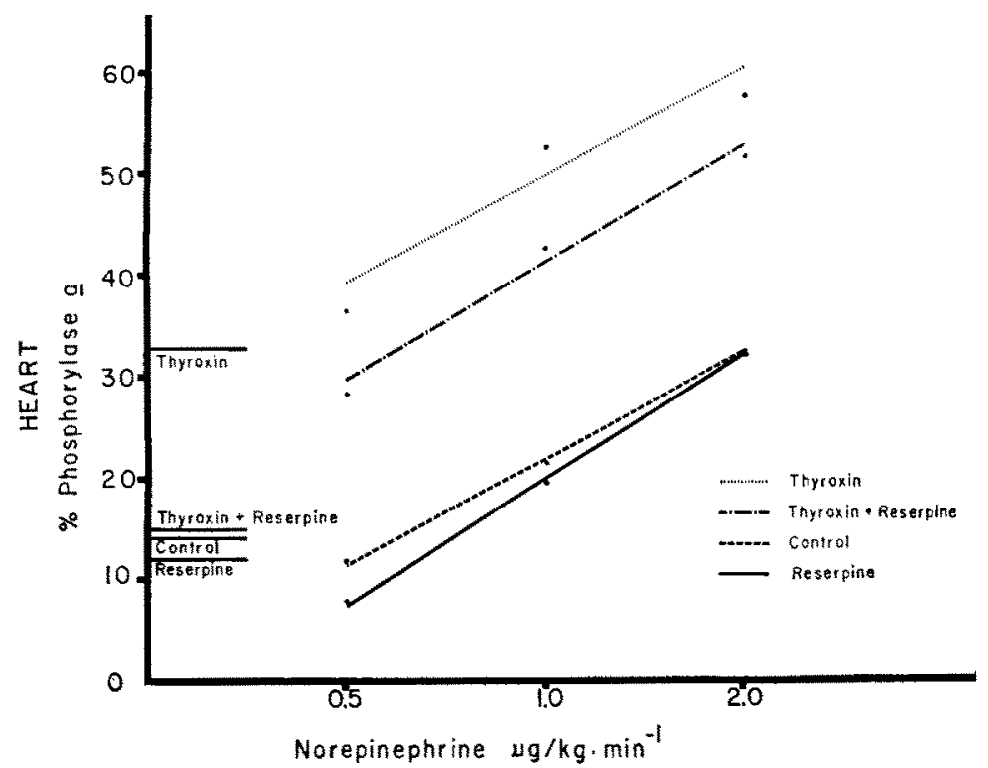

FIG. 2. Graph of the $\log$ dose -response curves for $l$-norepinephrine-induced rat heart phosphorylase $a$ activity. The curves are plotted from the data in Table 2 . The control mean phosphorylase levels (also from Table 2) for each treatment are shown as horizontal bars on the ordinate. The slopes of all four lines are not significantly different from one another.

in glycogen levels (Table 2). At the two larger doses of norepinephrine, phosphorylase $a$ levels rose from 14 to 21 and 33 per cent respectively. Only at the highest dose of norepinephrine $(2 \cdot 0 \mu \mathrm{g} / \mathrm{kg} \cdot \mathrm{min})$ was cardiac glycogen significantly reduced. After thyroxin, the infusion of the same three concentrations of norepinephrine produced phosphorylase $a$ values of 36,53 and 58 per cent respectively. Glycogen was significantly reduced after all doses of norepinephrine. An analysis of these data for interaction of thyroxin and norepinephrine revealed a positive interaction which could be indicative of potentiation at the $1.0 \mu \mathrm{g} / \mathrm{kg}$ dose for phosphorylase $a$ and at the two highest doses of norepinephrine for glycogen. The purpose of presenting the data appearing in Table 2 in graphic form (Fig. 2) was to determine the nature of the dose-response curve after the various treatments. After thyroxin and norepinephrine the slope of the dose-response curve did not appear to be different from that obtained after norepinephrine in euthyroid animals. It is apparent from the graph, however, that the norepinephrine log dose-response curve is shifted to the left in the thyroxintreated animals. It may also be noted that the phosphorylase $a$ value obtained at the highest dose of norepinephrine in these animals appears to he low (Table 2, Fig. 2) and may indicate a maximum which is artificially imposed upon the assay system, making it difficult to obtain phosphorylase $a$ values above $60 \%{ }^{17}$ 
Potentiation of the norepinephrine-induced increase of phosphorylase $a$ by thyroxin may also be illustrated in animals which, in addition, were treated with reserpine (Table 2). Euthyroid animals infused with the usual concentration of norepinephrine after reserpine showed no unusual response. At 1.0 and $2.0 \mu \mathrm{g} / \mathrm{kg} \cdot \mathrm{min}$ the per cent phosphorylase $a$ levels rose 7.5 and 20.5 respectively. The data were quite comparable to those seen in the control series. However, when thyroxin-treated animals received reserpine $12 \mathrm{hr}$ previously and were then challenged with norepinephrine, a potentiation of the norepinephrine infusion was unmasked, the per cent phosphorylase $a$ levels rising by $13 \cdot 5,28 \cdot 0$, and 37 at the three norepinephrine concentrations. Analysis of these data showed a positive interaction of thyroxin treatment and norepinephrine at all dose levels of norepinephrine (Table 2). A similar interaction was also demonstrated for glycogen loss at the two higher norepinephrine levels.

\section{Effect of various thyroxin treatments on phosphorylase a and glycogen levels}

Altering the dose and lime schedule of thyroxin produced changes that were not markedly different from those observed after the administration of $500 \mu \mathrm{g} /$ day for 14 to 20 days (Fig. 1). It may be observed, however, that the rise in phosphorylase $a$ in both these thyroxin-treated groups was lower than that observed with the original thyrotoxic group. Animals receiving $500 \mu \mathrm{g}$ /day for 1 week had cardiac phosphorylase $a$ levels of 24 per cent (compared to 18 per cent for this control series) while those animals receiving $50 \mu \mathrm{g} /$ day of $l$-thyroxin for 2 weeks had phosphorylase $a$ levels of 26 per cent. When these groups of animals were challenged with norepinephrine $(1.0$ and $2 \cdot 0 \mu \mathrm{g} / \mathrm{kg} \cdot \mathrm{min})$ an enhanced phosphorylase $a$ level was observed. Significant interaction of thyroxin and norepinephrine was demonstrated for the $50 \mu \mathrm{g} / \mathrm{day}$ thyroxin animals at a dose of $2 \mu \mathrm{g}$ norepinephrine $/ \mathrm{kg}$ and for both doses of norepinephrine in those animals receiving $500 \mu \mathrm{g} / /$-thyroxin day for 1 week.

A reduced cardiac glycogen was seen in those animals receiving $500 \mu \mathrm{g}$ thyroxin/ day for 1 week. Because of this reduced level it was not possible to show potentiation of glycogen loss after norepinephrine infusion. However, in the group of animals receiving $50 \mu \mathrm{g}$ thyroxin/day for 2 weeks such a potentiation could be demonstrated at both dose levels of norepinephrine.

Effect of norepinephrine infusion on cardiac phosphorylase a and glycogen levels in triiodothyronine-treated rats

In this study, rats were made thyrotoxic by the daily administration of $100 \mu \mathrm{g}$ of triiodothyronine for 3-5 days. As was observed with thyroxin treatment, these animals showed a marked cardiac hypertrophy. This group of animals (Fig. 3) also showed a marked increase in cardiac phosphorylase $a$ activity, having values of 28 per cent. The response to infused norepinephrine is also observed in Fig. 3. Significant potentiation of the norepinephrine-induced increase in phosphorylase $a$ could only be shown at the $1 \mu \mathrm{g} / \mathrm{kg} \cdot \mathrm{min}$ infusion levels. Figure 4 illustrates the glycogen changes measured in the same hearts as those in which the phosphorylase $a$ values were shown after triiodothyronine in the previous figure. While this hormone did not appear to lower the cardiac glycogen levels significantly when compared to hearts from control animals, the fall in glycogen after norepinephrine infusion was markedly potentiated at all infusion rates. 


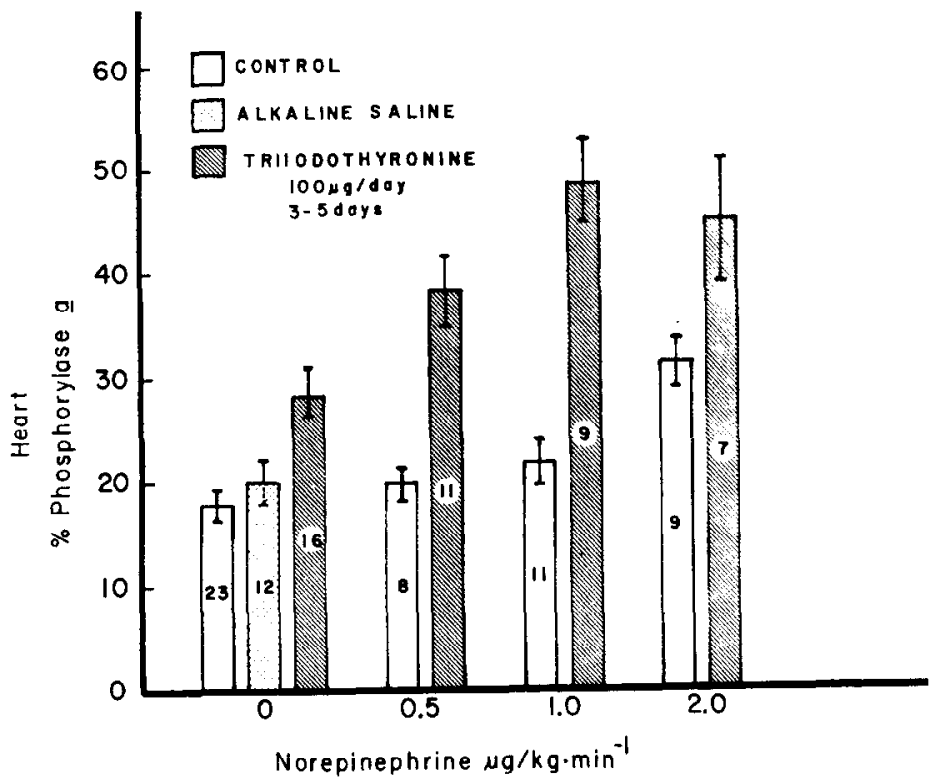

Fig. 3. Effect of norepinephrine infusion on cardiac phosphorylase $a$ activity in triiodothyroninetreated rats. Triiodothyronine dose was $100 \mu \mathrm{g}$ daily for 3-5 days. Numbers on the bar graphs indicate the number of animals in each group and the bars represent the mean values $:$ S.E. Values of animals receiving triiodothyronine alone were significantly higher than those of the control group receiving alkaline saline instead of triiodothyronine. Interaction of triiodothyronine and $1.0 \mu \mathrm{g}$ norepinephrine significant at $\mathrm{P}<0.05$ for the phosphorylase $a$ levels.

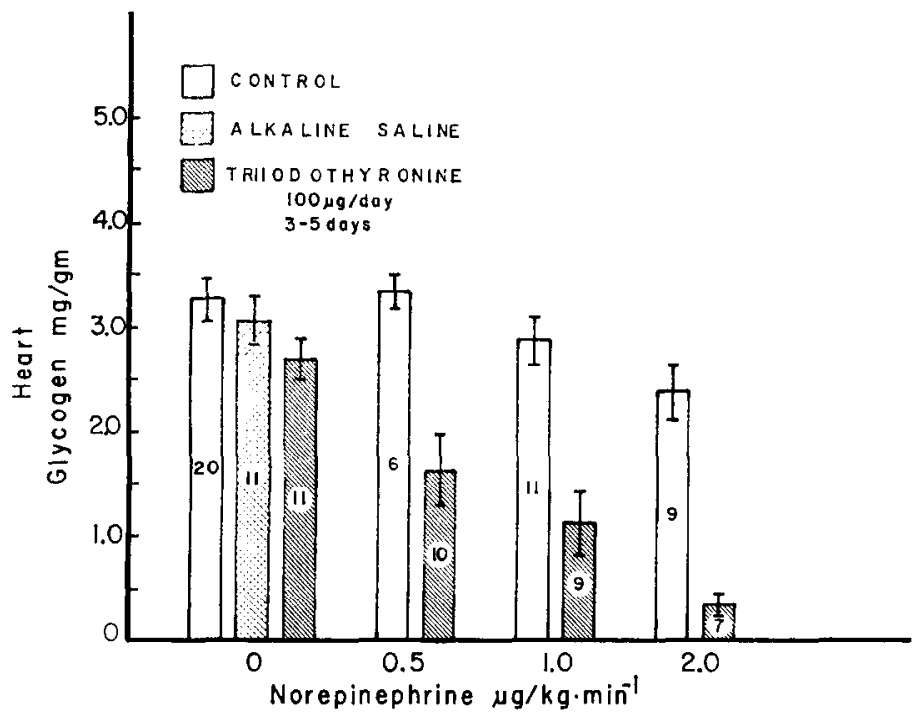

FIG. 4. Effect of norepinephrine infusion on rat cardiac glycogen content in triiodothyronine-treated animals. Drug treatment as in Fig. 3. Bars indicate the mean values $t$ S.E., and the numbers within the bars indicate the animals per group. Those animals receiving triiodothyronine alone had glycogen values not significantly different from controls. For glycogen loss, interaction of triiodothyronine and norepinephrine was significant $(P<0.05)$ at all dose levels. 


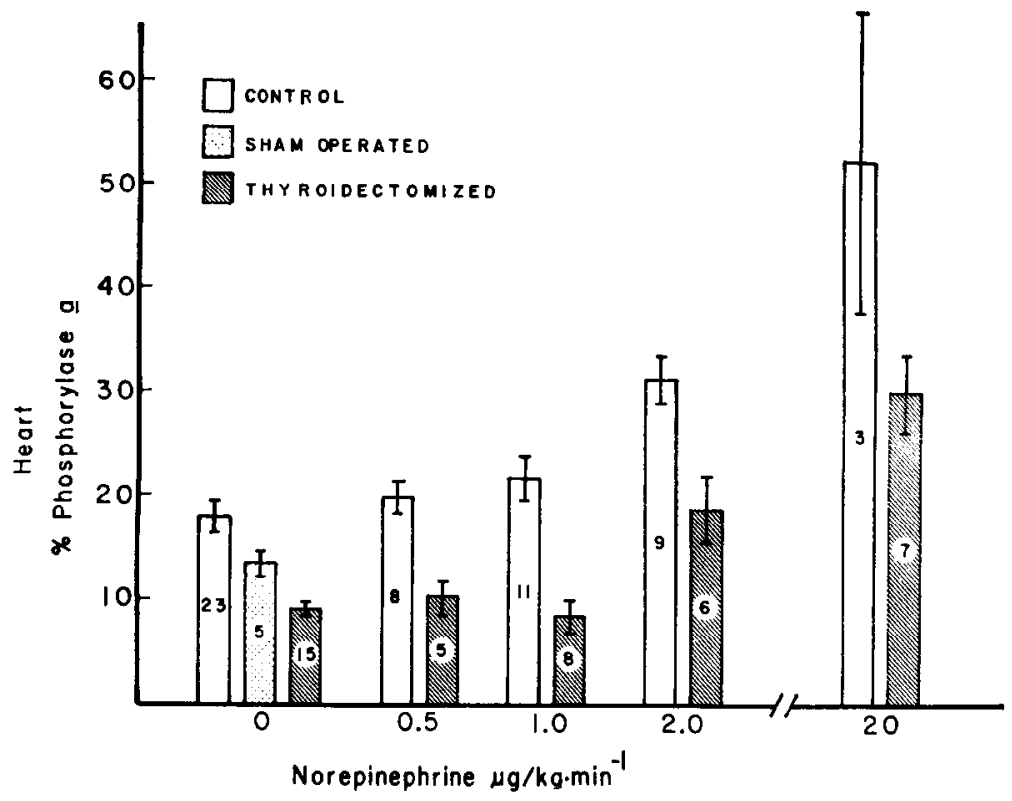

FIG. 5. Effect of norepinephrine infusion on cardiac phosphorylase $a$ activity in thyroidectomized rats. Controls were not significantly different from sham-operated, but both groups were significantly higher than the thyroidectomized animals $(P<0 \cdot 01)$. Responses to infused norepinephrine were not different from those seen with the untreated control group except at the highest dose of norepinephrine where significant interaction was demonstrated $(P<0.05)$ in the thyroidectomized animals. Bars represent mean values \pm S.E.

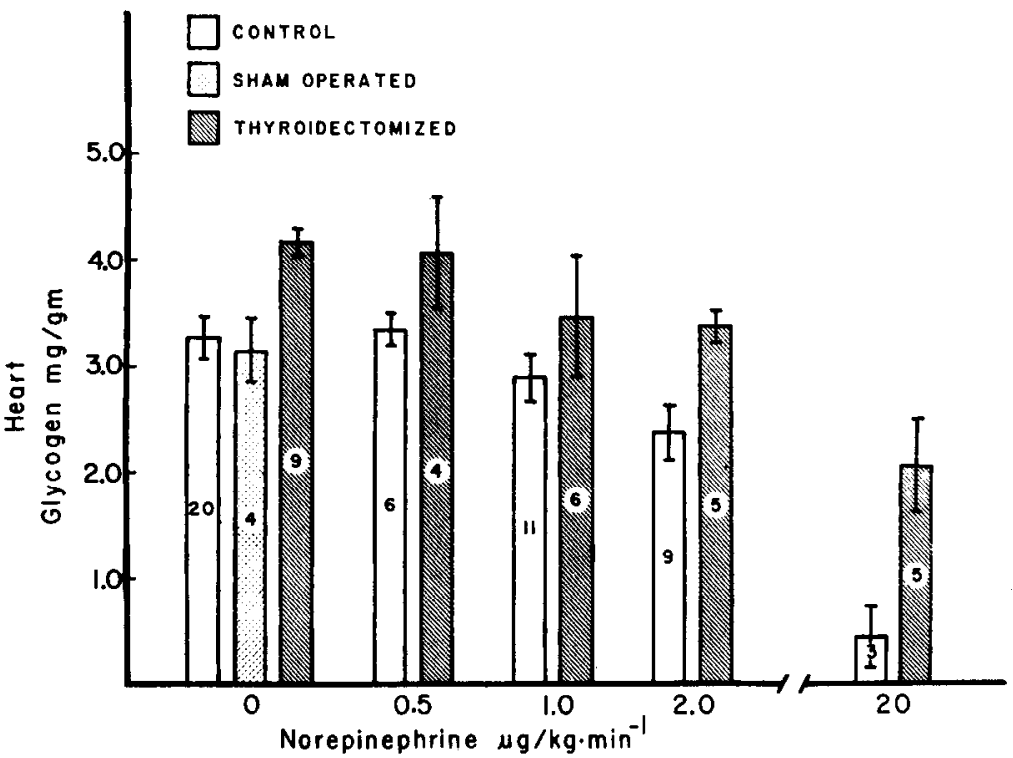

FIG. 6. Effect of norepinephrine infusion on rat cardiac glycogen content in thyroidectomized rats. Cardiac glycogen was significantly higher in thyroidectomized animals than in control or shamoperated rats given saline $(P<0.01)$. Only at the level of $20 \mu \mathrm{g}$ norepinephrine $/ \mathrm{kg}$ was there significant interaction $(P<0.05)$. 
Effect of norepinephrine infusion on cardiac phosphorylase a and glycogen levels in the thyroidectomized rats

Phosphorylase $a$ values in the hearts of thyroidectomized animals were $9 \%$, which was significantly lower $(\mathrm{P}<0.01)$ than either the sham-operated group or the untreated controls. These data are shown in Fig. 5. However, the cardiac phosphorylase $a$ response to infused norepinephrine was not different from that observed in untreated controls. Only at the very large dose of norepinephrine $(20 \mu \mathrm{g} / \mathrm{kg} \cdot \mathrm{min}) \mathrm{did}$ there appear to be any significant difference in response between thyroidectomized animals and untreated controls. The small number of animals (3) in this latter series results from the fact that this dose of norepinephrine when infused for 5 min caused death in more than half the animals. Thyroidectomized animals can apparently tolerate this amount of norepinephrine.

The cardiac glycogen data also reflected changes similar to those seen in phosphorylase $a$ levels in thyroidectomized animals (Fig. 6). While glycogen levels are significantly higher than in untreated controls the glycogen levels in response to infused epinephrine do not appear to be reduced to a greater extent after thyroidectomy. Again, only at toxic levels of norepinephrine $(20 \mu \mathrm{g} / \mathrm{kg} \cdot \mathrm{min})$ was there any enhancement of the effect on glycogen. Analysis of these data failed to show an interaction (inhibition) to the norepinephrine response after thyroidectomy either with respect to cardiac phosphorylase $a$ or glycogen.

\section{DISCUSSION}

From the data presented in this study it may be observed that the mcan control phosphorylase $a$ levels were approximately 14.2 per cent, with a standard error of 0.8 per cent for the largest group of rats studied. This compares favourably with values in the literature for excised rat heart and skeletal muscle phosphorylase $a$ levels, although lower values for perfused tissues and tissues frozen in situ have been reported. This has been discussed in detail elsewhere. While only negligible phosphorylase $a$ values have been reported for dog hearts ${ }^{21}$ by Wollenberger et al, more recently Drummond et al, ${ }^{22}$ using the technique described by Wollenberger, reported phosphorylase $a$ values of 3.6 per cent for the dog heart (open-chest preparation) and 10.8 per cent for perfused rat heart.

That the increase in myocardial phosphorylase $a$ levels in thyrotoxic rat might result from anoxia, as has been suggested, is negated by the fact that the tissue to be analyzed is frozen $4 \mathrm{sec}$ after opening the chest wall. The phosphorylase $a$ response reported by Wollenberger et al..$^{21}$ in dogs differed in the hyperthyroid animal only after an ischemic period of at least $15 \mathrm{sec}$.

The nature of myocardial response in thyrotoxicosis is a problem which has generated a considerable degree of controversy since it was reported that the major cardiovascular and metabolic effects of thyroxin could be abolished by sympathetic blockade and subsequently restored by the infusion of catecholamines. Since the original observations of Brewster, ${ }^{1}$ similar types of studies have been reported in thyrotoxic animals and in man by the use of drugs which produce either myocardial catecholamine depletion, 8,12 or prevent the nervous release of these neurohumors. ${ }^{10,11}$ On the basis of these and other findings it has been variously proposed that the sympathetic effect on the heart is to increase the availability of the catecholamines to the 
myocardial receptors. This may be accomplished by decreasing nonreactive binding or uptake, ${ }^{9,13}$ by altering the metabolism of the catecholamines, ${ }^{23-26}$ or by delivering an increased fraction of the cardiac output to the heart via the coronary vessels. ${ }^{13}$ That these actions probably do not explain the mechanism of action of thyroid hormone is suggested by studies of catecholamine excretion in animals, where no change ${ }^{27,} 28$ or only a moderate increase ${ }^{29}$ has been observed; or in hyperthyroid subjects where significant increases in catecholamine excretion have not been demonstrated. ${ }^{30,31}$ Observations of circulating epinephrine and norepinephrine have also shown no abnormal plasma levels elevation at rest or with exercise in hyperthyroid individuals (J. H. Siegel, unpublished observations), although elevated plasma levels have been observed in the thyrotoxic rat. ${ }^{26}$

While the possibility has also been entertained that thyroid hormone acts by decreasing the tissue-binding capacity for catecholamines or by decreasing the activity or the tissue content of enzymes which normally metabolize these neurohumors, Beaven et al32 found no increase in tissue norepinephrine turnover with thyroxin. Further, the present data show that reserpine, which blocks myocardial catecholamine binding, abolishes the thyroxin-induced myocardial activation of phosphorylase but appears to allow the potentiation by thyroxin of exogenously administered norepinephrine. In addition, it seems unlikely that a decrease in monoamine oxidase or $o$-methyl transferase activity is of major consequence in thyroid action, since Hornbrook and Brody ${ }^{14}$ have shown that drug-induced inhibition of monoamine oxidase resulted in elevated myocardial levels of catecholamines and failed to influence phosphorylase $a$ levels. It was also observed that cardiac catecholamine content is actually lowered by thyroid hormone treatment. ${ }^{14}, 32$

The present observations would appear to support the hypothesis that thyroid hormone modifies the response of the catecholamine receptors. ${ }^{1,33-36}$ The view that hypersensitivity of the receptor site is induced by thyroid hormone is supported by the observation that in thyroxin-treated animals there is an increase in myocardial phosphorylase $a$ activity and, more important, a potentiation of the norepinephrineinduced increase in phosphorylase $a$ levels. This potentiation action is more marked after reserpine, since control levels are reduced. This theory of thyroid action is also supported by the data that a $\beta$-adrenergic blocking agent, nethalide, is capable of reducing the thyroxin-induced increase in phosphorylase $a$ activity. That this agent does not completely abolish the adrenergic effects of thyroxin may reflect the competitive nature of the drug. However, the existence of a nonadrenergic, reserpinesensitive system cannot be ruled out by these data.

Although reserpine caused an increase in cardiac glycogen in untreated control rats, those animals receiving both thyroxin and reserpine had cardiac glycogen levels which were not significantly different from those animals receiving only thyroxin. An earlier study indicated that myocardial glycogen can be repleted in $30 \mathrm{~min}$ from the low level resulting from catecholamine administration. ${ }^{14}$ The results obtained with combined thyroxin and reserpine treatment suggest the possibility of a thyroxin effect on myocardial glycogen, which is independent of the phosphorylase $a$ level or the presence of catecholamines. This may represent a direct action of thyroxin on the enzymatic systems essential for glycogen synthesis or on the activities of other ratelimiting enzymes of the glycolytic pathway, such as phosphofructokinase, allowing the glycogen level to be maintained at a lower steady-state value. ${ }^{37}, 38$ 
Thus, the effect of thyroid hormone on the heart appears to be secondary to its effect upon the catecholamine receptor. Thyroxin itself appears to have no independent ability to increase phosphorylase $a$ activity when the catecholamines are depleted by reserpine. In the hyperthyroid animal after reserpine, norepinephrine produces a potentiation of cardiac phosphorylase $a$ levels.

In the thyroidectomized animal, however, while the magnitude of the norepinephrine response is unaltered, the base line is reduced. The failure to demonstrate a reduction in response to norepinephrine in thyroidectomized animals is not entirely inconsistent with the hypothesis that thyroid hormone regulates phosphorylase activation. It may be that this effect occurs only at elevated thyroid hormone levels so that at normal or subnormal hormone levels the enzyme is unaffected.

\section{REFERENCES}

1. W. R. Brewster, J. P. Isaacs, P. F. Osgood and T. L. King, Circulation 13, 1 (1956).

2. S. Ellis, Pharmacol. Rev. 8, 485 (1956).

3. F. L. Hoch, Physiol. Rev. 42, 605 (1962).

4. L. Hirvonen, Ann. Med. exp. Fenn, 34, 107 (1956).

5. W. H. MacMillan and M. J. Rand, J. Pharm. Pharmacol. 14, 257 (1962).

6. H. K. SAWYer, Jr. and H. J. LipNer, Amer. J. Physiol. 201, 264 (1961).

7. J. B. van der Schoor, A. Kosen and N. C. Moran, Fed. Proc. 22, 364 (1963).

8. J. J. Canary, M. SchaAf, B. J. Duffy, JR. and L. H. KYle, New Engl. J. Med. 257, 435 (1957).

9. H. J. Dengler, Verh. dtsch. Ges. Kreisl.forsch. 27, 252 (1961).

10. T. E. Gaffney, E. Braunwald and R. L. Kahler, New Engl. J. Med. 265, 16 (1961).

11. W. Y. LeE, D. BronsKY and S. S. WALdSTein, J. clin. Endocr. 22, 879 (1962).

12. I. E. Mendelsohn, A. Bassett, J. J. Kelly and B. F. Hoffman, Amer. J. Cardiol. 7, 694 (1961).

13. R. J. Wurtman, I. J. Kopin and J. Axelrod, Endocrinology 73, 63 (1963).

14. K. R. HoRNBrooK and T. M. BRody, J. Pharmacol. exp. Ther. 140, 295 (1963).

15. W. Z. Hassid and S. Abraham, Methods iv Enzymology, ed. S. P. Colowick and N. O. Kaplan, vol. 3, p. 34. Academic Press, New York (1957).

16. N. Nelson, J. biol. Chem. 153, 375 (1944).

17. G. T. CORI and B. IllingwORTH, Biochim. biophys. Acta 21, 105 (1956).

18. G. W. SNEDECOR, Statistical Methods, 4th ed. Univ. of Iowa Ames (1946).

19. W. Dock and J. K. LewIS, J. Physiol. (Lond.) 74, 401 (1932).

20. C. T. Liu and R. R. Overman, Proc. Soc. exp. Biol. (N.Y.) 117, 232 (1964).

21. A. Wollenberger, E. G. Krause and L. Macho, Nature (Lond.) 201, 789 (1964).

22. G. I. Drummond, J. R. E. Valadares and L. DunCan, Proc. Soc. exp. Biol. (N. Y.) 117, 307 (1964).

23. A. D'Iorio and J. LeduC, Arch. Biochem. 87, 224 (1960).

24. A. Spinks and J. H. BurN, Brit. J. Pharmacol. 7, 93 (1952).

25. U. Trendelenbero, Brit. J. Mharmacol. 8, 454 (1953).

26. M. ZiLE and H. A. LardY. Arch. Biochem. 82, 411 (1959).

27. R. T. Jones and W. D. Blake, Amer. J. Physiol. 193, 375 (1958).

28. R. SChNeCKCloth, cited by U. S. von Euler, Noradrenaline, p. 301. Thomas, Springfield, 111 (1956).

29. P. H. Stern and T. M. Brody, J. Pharmacol. exp. Ther. 141, 65 (1963).

30. T. S. HARrison, J. surg. Res. 1, 77 (1961)

31. R. J. Levine, J. A. OAtes, A. Vendsalu and A. SJoerdsma, J. clin. Endocr. 22, 1242 (1962).

32. M. A. Beaven, E. Costa and B. B. Brodie, Life Sci. 4, 241 (1963).

33. M. E. M. SAWYer and M. G. Brown, Amer. J. Physiol. 110, 620 (1935).

34. E. S. Let, JK., Amer. J. Physiol. 135, 452 (1942).

35. J. E. Murray and J. J. Kelly, Ann. intern. Med. 51, 309 (1959).

36. J. B. Collip, D. L. Thomson and G. J. Toby, J. Physiol. (Lond.) 88, 191 (1936).

37. P. B. Garland, A. J. Randle and E. A. Newsholme, Nature (Lond.) 200, 169 (1963).

38. J. V. Passoneau and O. H. Lowry, Biochem. biophys. Res. Commun. 7, 10 (1962). 